\title{
LEXICAL KNOWLEDGE OF SERBIAN L1 ENGLISH L2 LEARNERS: RECEPTION VS. PRODUCTION ${ }^{1}$
}

\begin{abstract}
The acquisition of lexical knowledge in a second/foreign language is often
Abstract

investigated by means of vocabulary size tests which assess two aspects of the learners' competence: reception and production. Estimates of these two dimensions, as well as the (potential) gap between them, have important pedagogical implications in that they indicate the degree to which the learners can comprehend or use the language autonomously. Therefore, the aim of this paper is to explore the vocabulary size of three generations of B2-level L2 learners (CEFR), first-year students majoring in English at the Faculty of Philology and Arts in Kragujevac, Serbia, by means of Vocabulary Levels Tests (Laufer \& Nation, 1999; Nation, 1990). The results of the statistical analyses show that the receptive vocabulary of Serbian $L 2$ learners is much more developed than their productive vocabulary, and that the gap between lexical production and reception changes depending on the frequency of the lexemes and the proficiency level of L2 learners. The findings imply that, at the primary and secondary level of education, more attention should be paid to the development of productive lexical knowledge which is crucial not only for success in Englishdegree courses but communication in English in general.
\end{abstract}

Keywords: lexical knowledge, vocabulary teaching, L2, reception, production.

1 This paper was supported by project grant 178014 from the Ministry of Education, Science and Technological Development of the Republic of Serbia. Its shorter version was presented at the 2nd international conference Science and Modern University, held at the Faculty of Philosophy in Niš, November 16-17, 2012. 


\title{
ЛЕКСИЧКО ЗНАЊЕ УЧЕНИКА ЕНГЛЕСКОГ ЈЕЗИКА КАО СТРАНОГ КОЈИМА ЈЕ МАТЕРЊИ ЈЕЗИК СРПСКИ: РЕЦЕПЦИЈА НАСПРАМ ПРОДУКЦИЈЕ
}

\begin{abstract}
Ancmракт $\begin{aligned} & \text { Усвајање лексичког знања у другом/страном језику неретко се } \\ & \text { истражује применом тестова величине лексичког фонда који испитују }\end{aligned}$ два аспекта компетенције ученика: рецептивни и продуктивни. Процене величине ове две димензије, као и раскорака који између юих (можда) постоји, имају важне педагошке импликације будући да одређују степен у коме ученици могу да разумеју, односно да самостално користе језик. У складу с тим, ииљ овог рада је да истражи величину лексичког фонда на узорку три генерачије ученика енглеског језика као страног, студената прве године англистике на Филолошко-уметничком факултету у Крагујевиу, чији се ниво језичке компетенције у $J 2$ процењује као Б2 (према Заједничком европском оквиру), и то уз помоћ Vocabulary Levels Tests (Laufer \& Nation, 1999; Nation, 1990). Резултати cmamистичких анализа показују да је рецептивно лексичко знање ученика енглеског језика као страног којима је матерњи језик српски много развијеније од њиховог продуктивног знања, као и да се однос између продукције и рецепције мења, у зависности од фреквентности лексема и знања ученика. На основу ових налаза закључујемо да би на примарном и секундарном нивоу образовања било потребно посветити више пажње развоју продуктивног лексичког знања ученика јер је оно од суштинске важности, не само за успех на студијама англистике, већ и комуникацију на енглеском уопите.
\end{abstract}

Кључне речи: лексичко знање, настава вокабулара, J2, рецепција, продукција.

\section{ЗНАНИЕ ЛЕКСИКИ АНГЛИЙСКОГО КАК ИНОСТРАННОГО ЯЗЫКА У СЕРБСКОГОВОРЯЩИХ УЧЕНИКОВ}

\footnotetext{
Усвоенность лексики иностранного или второго языка часто

Резюме

проверяется с применением тестов объема лексического фонда, которые определяют два аспекта компетенции учащихся: рецептивный и продуктивный.Оценкаобъемаэтихдвухизмерений, атакжевозможногонесовпадения между ними, несет важные педагогические последствия, так как определяет уровень понимания и самостоятельного использования языка. В данной работе исследуется объем лексического фонда на примере трех поколений учеников английского языка как иностранного, студентов первого курса англистики Филологическохудожественного факультета в Крагуеваце, уровень языковой компетенции которых оценивается как Б2 (Общеевропейские компетенции владения иностранным языком). В исследовании был использован Vocabulary Levels Tests (Лауфер и Нейшен, 1999; Нейшн, 1990). Результаты статистического анализа показали, что уровень
} 
Lexical knowledge of Serbian L1 English L2 learners: reception vs. production

рецептивных видов знания лексики английского языка сербскоговорящих учеников более высокий, чем уровень языковой продукции, а отношение между рецептивным и продуктивным лексическим запасом меняется в зависимости от частоты лексем и знаний учеников. На основе этих результатов, можно сделать вывод, что в обучении необходимо уделять больще внимания развитию продуктивных лексических знаний у учеников, потому что это важно не только для успешной учебы на факультете, но и для коммуникации на английском языке.

Ключевые слова: лексические знания, обучение лексике, второй язык, рецептивные и продуктивные виды речевой деятельности.

\section{Introduction}

The crucial role of lexical knowledge in L2 learning ${ }^{2}$ is nowadays no longer disputed. Knowing all the grammatical rules of a given language will not enable learners to communicate effectively in real life situations if they lack lexical resources. A widespread effort aimed at comprehending the process of $L 2$ acquisition has over the years resulted, inter alia, in a far-reaching conclusion: given that knowing a word encompasses knowing its form, meaning and use (Nation, 2001: 35), the nature of lexical knowledge has aptly been described as incremental. It gradually increases, both qualitatively and quantitatively, as a learner proceeds along the different stages of the developmental route.

Even though there are, according to some conservative estimates, more than 50,000 word families ${ }^{3}$ in English (Goulden et al., 1990), knowing a much smaller number of them will suffice L2 learners for comprehension of a written or spoken text. When learners have acquired the most frequent 2,000 word families in English, this will enable them to understand about $80 \%$ of the words which appear in miscellaneous texts regardless of the subject matter (Carter, 1998; Nation, 1990). To be able to read authentic texts with ease, they have to master at least 3,000 to 5,000 word families (Schmitt \& McCarthy, 1997: 103). Nevertheless, being able to recognize and understand words upon seeing or hearing them (i.e. receptive or passive competence), represents but one side of the lexical coin: for meaningful interaction with others, knowledge of how to use words is needed (i.e. productive or active competence). As Nation and Waring (1997) report,

2 In this paper, the difference between learning English as a second language (i.e. L2 context) and as a foreign language (i.e. EFL context) will not be insisted upon. L2 will stand for both of these contexts notwithstanding the fact that they represent distinct learning situations.

3 A word family has repeatedly been defined as a set of words containing the base word, all of its inflections and its common derivatives (Schmitt, 2000: 2). For instance, stimulate, stimulates, stimulated, stimulating, stimulation, stimulative, and stimulator can all be considered members of the same word family since they are closely related in form and meaning. In this paper, we will adopt the aforesaid definition of a word family and use the term as a synonym for word, in keeping with other researchers' work in this area (e.g. Laufer \& Nation, 1995; Ozturk, 2012; Zhong \& Hirsh, 2009). 
productive knowledge of 2,000-3,000 word families can be deemed a sound basis for the purpose of speaking and writing. Unfortunately, vocabulary size of many a learner, even receptive let alone productive, might fail to meet the recommended threshold of 2,000-3,000 words in spite of the number of years invested in learning the language in an instructional L2 setting (cf. Milton, 2009). Taking the aforementioned into consideration, it becomes clear that the vocabulary size (VS) of L2 learners, both receptive and productive, constitutes a vital element in the process of L2 learning and teaching, one that merits special attention in the classroom.

It is generally assumed that receptive vocabulary of $L 2$ learners is larger than their productive vocabulary. Several estimates of vocabulary size have indicated that receptive vocabulary is double that of productive vocabulary or even larger (Clark, 1993; Eringa, 1974; Marton, 1977). Contrary to that, others have suggested that the gap between lexical reception and production is rather modest, with the two vocabularies being practically of equal size (Annen, 1933; Seashore \& Eckerson, 1940; Takala, 1984). The two opposing viewpoints have arisen as a consequence of the methodological design of these studies, i.e. the chosen testing method, and the subsequent interpretation of the results. In recent years, researchers have strived to explore the relationship between receptive and productive lexical knowledge of $\mathrm{L} 2$ learners by employing testing instruments that do not favor either reception or production. Many of them have utilized the Vocabulary Levels Tests (Laufer \& Nation, 1995; Nation, 1990) whose validity, reliability and practicality in terms of assessing both dimensions of vocabulary knowledge had been challenged and proved (cf. Laufer \& Nation, 1999; Read, 1988).

In the next few paragraphs, we will briefly outline the findings of research studies that focused on lexical knowledge of English L2 learners by taking advantage of the cued Vocabulary Levels Tests ${ }^{4}$ or their variations (e.g. Nation, 1993; Schmitt et al., 2001).

\section{Research background}

Waring's (1997) exploration of the gap between the receptive and productive aspect of lexical knowledge in Japanese L1 English L2 learners, first or second year English majors, revealed that the subjects' receptive vocabulary was consistently larger than their productive vocabulary, across all word levels. When the learners were divided into three proficiency groups according to their achievement on both tests (i.e. the lower, middle and upper vocabulary size group) and their scores compared, the author reached the conclusion that the lexical profiles were roughly the same across all groups, with the upper group demonstrating the slightest difference between the scores achieved at each level of the receptive and productive vocabulary test.

In a cross-sectional study that addressed the issue of lexical progress in Hebrew L1 English L2 learners, Laufer (1998) compared the vocabulary sizes of two groups of

$4 \quad$ A detailed design of the Vocabulary Levels Test (Nation, 1990) and Productive Vocabulary Levels Test (Laufer \& Nation, 1995) is presented in section 3.2. of this paper (i.e. Research instruments). 
learners: $10^{\text {th }}$ and $11^{\text {th }}$ graders. The vocabulary test results showed that the younger group of learners knew roughly 1,900 word families receptively and 1,700 productively. On the other hand, the older group of learners knew approximately 3,500 word families receptively and 2,550 productively. As we can see, the receptive and productive vocabulary size was, for all practical purposes, equally developed in younger learners, with reception slightly ahead of production. During one year, however, the learners managed to add about 1,600 word families to their receptive vocabulary and 850 word families to their productive vocabulary. This led Laufer to hypothesize that graduates of Israeli high schools are expected to have learnt approximately 3,500-4,000 word families in English. At the same time, statistically significant correlations established between receptive and productive vocabulary size of both age groups ( $r=0.67$ vs. 0.78 ) indicated that the better results which the learners achieved on the receptive VS test, the better their performance on the productive VS test. The author also found that the bigger a learner's receptive vocabulary, the wider the gap between it and productive vocabulary and vice versa.

In the Spanish formal teaching and learning context, Olmos (2009) investigated the receptive vocabulary size of English L2 learners in their final year of secondary education. Even though the participants in her study were believed to have reached a stage in vocabulary acquisition where they could function autonomously in everyday communication in English, since English is a compulsory subject within the Spanish school system for a period of at least eight years, her findings showed that their vocabulary size was fairly limited, falling short of 1,000 words. In other words, these L2 learners failed to develop elementary competence in the target language that would make it possible for them to comprehend 1,000 high frequency words of English in oral or written form. This conclusion casts a shadow over the efficiency of educational practices in Spain as regards $L 2$ teaching and learning.

\section{The study}

Bearing in mind that the studies heretofore conducted in non-Serbian L2 learning contexts have indicated that receptive and productive vocabulary size of L2 learners, nearing the end of secondary or embarking upon tertiary level of education, can vary significantly, we set out to explore the issue of lexical acquisition in Serbian L1 English L2 learners who are at a similar educational stage in life. For this purpose, the following research questions were formulated:

1. What is the gap between receptive and productive vocabulary size of Serbian L2 learners?

2. Does the relationship between receptive and productive vocabulary change over the frequency word levels? 


\section{Participants}

The subjects who voluntarily participated in this study were 207 Serbian L1 English L2 learners. More precisely, the data was collected from three consecutive generations of freshmen enrolled in the English language and literature program at the Faculty of Philology and Arts in Kragujevac, spanning the years 2010-2012:

- academic year 2010-2011: 68 students

- academic year 2011-2012: 67 students

- academic year 2012-2013: 72 students

The learners' L1 was, invariably, determined to be Serbian by means of an anonymous questionnaire which the students filled prior to the vocabulary testing. In addition, the learners' level of proficiency in English was estimated as B2 (as specified by the Common European Framework of Reference) by means of the university entrance exam, a prerequisite for enrollment in tertiary level studies of English at the Faculty of Philology and Arts.

\section{Research instruments}

Two vocabulary size tests, examining the receptive and productive dimension of the learners' lexical knowledge, were employed as research instruments for the purpose of this study. Both of them were borrowed from other researchers on account of their practicality and reliability: Nation's (1990) Vocabulary Levels Test was used as a receptive measure of L2 lexical knowledge and Laufer and Nation's (1995, reprinted in Nation, 2001) Productive Vocabulary Levels Test as its productive counterpart. ${ }^{5}$ These tests were constructed in accordance with the same word frequency principle, each consisting of five sections: the 2,000-word level; the 3,000-word level; the 5,000-word level; Academic Vocabulary/University Word Level and the 10,000-word level. The word bands correspond to the first 2,000 most frequent words in English, the next 1,000 (i.e. the 3,000-word level) and so on, while the university word level represents subtechnical academic vocabulary. The underlying assumption is that by testing learners merely on a sample of words drawn from different word frequency bands, the teachers can gain insight into their general lexical ability. ${ }^{6}$

Both tests consist of 90 test items, 18 per level, which renders the results comparable across word bands. The tests are, nevertheless, markedly different in format

The Productive Vocabulary Levels Test is also known as the controlled active or semiproductive vocabulary test. It is worth pointing out that both the receptive and productive version of the Vocabulary Levels Tests (e.g. Nation, 2001) represent tests of lexical competence, not performance as they do not measure the words the learners can use receptively or productively (Ozturk, 2012: 4).

6

Each test item represents 55 words (1,000 divided by 18$)$ of the 1,000 frequency word band. A score of 14 out of 18 on a particular level, for instance, implies that the learner knows 770 words out of the 1,000 at that level, and does not know 230 (interpretation in line with Nation, 2008: 143). 
and their inherent sense of difficulty: to solve the receptive vocabulary size test learners need to match 90 decontextualized items with their synonyms or short definitions whereas the productive vocabulary size test requires of the learners to complete the words whose first letters are offered in 90 sentences, e.g.

$\begin{aligned} & \text { Receptive vocabulary size task } \\ & 1 \text { business } \\ & 2 \text { clock } \\ & 3 \text { horse }\end{aligned} \begin{aligned} & \text { part of a house } \\ & 4 \text { pencil }\end{aligned}$
$\begin{aligned} & 5 \text { shoe } \\ & 6 \text { wall }\end{aligned}$

Productive vocabulary size task

He was riding a bic (bicycle)

According to Cobb's (2000) interpretation, for the learners' competence to extend across any of the word bands, at least 15 out of 18 items (or 83\%) have to be solved correctly on a particular section of the test. If a learner achieves fewer than 15 points at any level, his/her score is considered weak.

\section{Procedure and scoring}

The participants completed the receptive and productive vocabulary test in their regular vocabulary classes at the very start of three successive academic years, i.e. during the first two weeks of October in 2010,2011 and 2012. To minimize exhaustion, the testing sessions were consistently held one week apart, in the following order: first the receptive vocabulary test was distributed, then the productive one. At the onset of each lexical task, the teaching instructor-researcher provided a brief explanation in Serbian about the contents of the test, along with a few examples demonstrating how the items should be solved. Moreover, it was made clear that the data was being collected exclusively for research purposes and that the ensuing results would have no impact whatsoever on the course grades. Despite the fact that there was no time limit on either of the lexical tasks, the learners succeeded in completing them in less than 45 minutes' time.

With regard to the scoring procedure, each response on the vocabulary tests was marked as either correct or incorrect ( 0 or 1 point awarded). It is worth noting that a more lenient approach was applied in the scoring of the Productive Vocabulary Levels Test, in keeping with Laufer's (1998) reasoning: mistakes pertaining to grammatical form (e.g. accumulate instead of accumulated) or spelling (e.g. carreer instead of career) were not penalized as long as the lexical meaning was recognizable.

The collected data was analyzed quantitatively using the statistical program SPSS, version 17.0. 


\section{Results and discussion}

To answer research question one, we compared the results obtained on the receptive and productive vocabulary size test. Considering that the maximum number of points on both tests was 90 (18 per level), we arrive at the conclusion that the learners' receptive lexical knowledge is much more developed than their productive knowledge (Table 1). This is evident both in the total number of points achieved on each of the tests as well as across all word bands. A statistically significant difference in mean scores, which emerged after a t-test was performed, lends support to these findings ( $p<0.001)$.

Table 1. A comparison of L2 learners' receptive and productive lexical knowledge

\begin{tabular}{lcccccccc} 
& \multicolumn{2}{c}{ Receptive VS } & \multicolumn{2}{c}{ Productive VS } & \multicolumn{3}{c}{ Paired differences } \\
\cline { 2 - 10 } & Mean & SD & Mean & SD & Mean & t & $p$ & df \\
\hline 2,000 & 16.69 & 1.57 & 14.04 & 2.74 & 2.64 & 15.94 & 0.000 & 206 \\
\hline 3,000 & 16.41 & 1.93 & 7.81 & 3.02 & 8.60 & 49.51 & 0.000 & 206 \\
\hline 5,000 & 12.22 & 2.87 & 4.95 & 2.93 & 7.27 & 39.63 & 0.000 & 206 \\
\hline AV/UWL & 12.98 & 2.45 & 6.86 & 3.00 & 6.12 & 38.80 & 0.000 & 206 \\
\hline 10,000 & 6.81 & 3.61 & 3.36 & 2.17 & 3.44 & 16.25 & 0.000 & 206 \\
\hline Total & 65.14 & 9.98 & 37.02 & 11.98 & 28.12 & 57.60 & 0.000 & 206 \\
\hline
\end{tabular}

When we interpret the results in line with the recommended criterion (cf. Cobb, 2000), we discover that the learners' performance could be deemed satisfactory solely on the 2,000- and 3,000-word frequency band of the receptive VS test (16.69 vs. 16.41). The frequency of the test items obviously had a bearing on the learners' achievement across the levels - as it decreased, it was followed by an increasingly poorer results. This pattern is broken, however, at the level of academic lexis where we notice a rise in mean scores on both versions of the VS test. If we convert the overall scores on the two tests into an approximate calculation of word families, we realize that the total receptive VS equals roughly 4,100 word families whereas the total productive VS equals about 2,500 word families. ${ }^{7}$ Coupled with the fact that the learners did not show confidence in solving the 2,000-word band items on the productive VS test (see Table 1 above), these figures suggest that the learners' productive competence in English seriously lags behind their receptive competence. Hence, we can surmise that the primary and secondary level of formal education in Serbia provided the learners with a sound basis for comprehension in English but did not equally develop their productive lexical skills. At the same time, these results serve as an indication of the lexical gaps which should be filled at the tertiary level of education. Although students will be able to read authentic texts in English with relative ease, when it comes to their productive abilities, they will need to add to their vocabularies a significant number of the first 3,000 most frequent words in English. A

$7 \quad$ The calculations were performed in accordance with Laufer's (1998) recommendations. Given that the learners' achievement on the final level of the VS tests (i.e. the 10,000-word band) was rather poor, we chose to disregard these results when converting the overall scores into the approximate number of word families. 
plethora of activities aimed at boosting the learners' productive lexical knowledge in the L2 is therefore highly desirable in the tertiary level classroom. ${ }^{8}$

To answer research question two, we calculated the ratio between the scores achieved on the productive and receptive test of lexical knowledge (productive VS $\times 100$ / receptive VS). The figures presented in Table 2 suggest that the ratio between lexical production and reception gradually decreases along with the decreasing frequency of the test items. In other words, the more frequent the items, the higher the ratio and vice versa. This in turn implies that the gap between lexical production and reception widens at each level as the words become less and less familiar to the learners: the gap is the narrowest at the 2,000-word frequency band and the broadest at the 5,000-word frequency band.

Table 2. The production vs. reception ratio across word frequency bands

\begin{tabular}{ll} 
& P/R ratio (\%) \\
\hline 2,000 & 84.12 \\
\hline 3,000 & 47.59 \\
\hline 5,000 & 40.50 \\
\hline AV/UWL & 52.85 \\
\hline 10,000 & 49.33 \\
\hline
\end{tabular}

If a learner knows a high frequency word receptively, the likelihood of his/her knowing the word productively is very high (84.12\%) but if s/he knows a lower frequency word receptively, the probability that the word will also be known productively is much lower (40.50\%). Somewhat discordant results manifested at the level of academic lexis and the 10,000-word frequency level, where we observe a rising tendency in the ratio between production and reception, can perhaps be attributed to two factors: the learners' familiarity with the academic vocabulary and their proficiency level in English. To explain the former, we hypothesize that the learners had been introduced to the genre-specific lexis peculiar to academic texts at the secondary level of education. Considering that B2-oriented (CEFR) English textbooks and workbooks contain various texts as well as sections dedicated to the development of formal writing skills, this seems likely. Furthermore, since the university entrance exam at the Faculty of Philology and Arts in Kragujevac incorporates a writing segment, the learners could have prepared for this task by specifically working on academic topics and their genre-related vocabulary. The latter could, on the other hand, be ascribed to the fact that a relatively small number of students, the most proficient ones, attempted to solve the final part of the test (i.e. the 10,000-word level). These learners had performed well across all previous word frequency levels and, as a result of their advanced competence in English, the gap between lexical production and reception at this word frequency band is smaller than the one detected at the 3,000- and 5,000-word portions of the test.

The gap between lexical reception and production was investigated in more detail by dividing the learners into two groups according to their performance on the

$8 \quad$ For more information regarding practical activities designed for the development of productive lexical knowledge in English, see Nation (1990), Nation (1994) and Nation (2001). 
receptive VS test: the upper VS group and lower VS group (Table 3). ${ }^{9}$ We chose to discard the data obtained for the 10,000-word frequency band for fear of biasing the results since a very small number of students, in both groups, tried to solve this part of the test and only a few had any success in doing so.

Table 3. The production vs. reception ratio of two different VS groups

\begin{tabular}{lccccc} 
& $\mathrm{N}$ & 2,000 & 3,000 & 5,000 & AV/UWL \\
\hline $\begin{array}{l}\text { Upper } \\
\text { VS group }\end{array}$ & 72 & $89.59 \%$ & $57.08 \%$ & $50.71 \%$ & $62.68 \%$ \\
\hline $\begin{array}{l}\text { Lower } \\
\text { VS group }\end{array}$ & 121 & $81.98 \%$ & $42.67 \%$ & $33.51 \%$ & $47.55 \%$ \\
\hline
\end{tabular}

The listed ratios suggest that the gap between receptive and productive lexical knowledge is much narrower for the upper VS group. For these students, the gap slowly widens as the frequency of the tested items declines, going from an approximate $90 \%$ chance that a word is known productively when it is known receptively (the 2,000-word level) to a $50 \%$ chance (the 5,000-word level). While the gap widens at the 3,000- and 5,000-word level, it narrows strikingly at the academic lexis level. The results are similar, but the gap between lexical production and reception widens much more dramatically, for the lower VS group. We see that for them, the likelihood of knowing a high frequency word productively, if it is known receptively, is about $80 \%$ (the 2,000-word level). As the frequency of the words drops, so does the probability that they will be known productively - there is, approximately, a 30\% chance that a 5,000-word level word will be known. However, even for learners with lower VS, the gap between receptive and productive lexical knowledge conspicuously narrows at the level referring to academic vocabulary. Accordingly, we can conclude that the smaller VS a learner has, the wider the gap between lexical production and reception. This refutes claims made by Laufer (1998) vis-à-vis the lexical profile of different proficiency groups.

The relationship between lexical reception and production was further explored by dint of correlational techniques (Table 4).

Table 4. Pearson's correlations between lexical reception and production

\begin{tabular}{llc} 
& $r$ & Sig. (two-tailed) \\
\hline 2,000 & $0.499^{* * *}$ & 0.000 \\
\hline 3,000 & $0.566^{* *}$ & 0.000 \\
\hline 5,000 & $0.587^{* *}$ & 0.000 \\
\hline $\mathrm{AV} / \mathrm{UWL}$ & $0.670^{* *}$ & 0.000 \\
\hline 10,000 & $0.540^{* *}$ & 0.000 \\
\hline Total & $0.811^{* *}$ & 0.000 \\
\hline${ }^{* *}$ Correlation is significant at the 0.01 level (two-tailed).
\end{tabular}

9 The groups were formed in line with the following scores: 70-90 pts (upperVS group) and 50-69 pts (lower VS group). Fourteen students whose scores did not reach the 50-point threshold were excluded from this analysis. 
Looking at Table 4, we see that statistically significant, moderate correlations were noted both between the overall scores on the receptive and productive VS test and the scores achieved at the individual levels of these two tests $(p<0.001)$. The strength of the relationship is weaker at the 2,000- $(r=0.499), 3,000-(r=0.566)$ and 10,000-word level $(r=0.540)$ than at the 5,000-word level $(r=0.587)$ and the academic lexis level $(r=0.670)$. Given that the correlational coefficients are all positive, we realize that the better the students' performance on the receptive VS test, the better their results on the productive VS test. Such findings indicate that the learners who possess a well-developed receptive vocabulary, also possess a fairly developed productive vocabulary. Drawing on these results, and taking into consideration the fact that no student gained higher scores on the productive VS test than on the receptive VS test, we can safely assume that the receptive VS test functions as a good predictor of the learners' productive lexical knowledge. This supports the aforementioned results relating to the lexical productionreception ratios. It corroborates Laufer's (1998) and Zhong and Hirsh's (2009) reports on the relatedness of lexical reception and production in L2 learners. What is more, the foregoing conclusions imply that, in the L2 classroom setting, teachers can save time allotted for the assessment of their learners' competence in English by relying solely on the receptive VS test. It provides a quick and practical appraisal of a learner's receptive VS and at the same time allows teachers to gain an understanding of a learner's productive VS. It goes without saying that the relationship between receptive and productive lexical knowledge is neither linear nor uniform (cf. Webb, 2009), so predictions based on the receptive VS test will probably not apply to the entire population of $L 2$ learners, as Zhong and Hirsh (2009) admit. Yet for the sake of classifying learners into various proficiency groups, we believe the receptive VS test has proven to be a tool that might just serve this purpose.

\section{Conclusion}

Measurement of lexical knowledge by means of the frequency count method figures prominently in the field of $L 2$ acquisition because it enables teachers to realize how far along the lexical continuum their learners have advanced. Estimates of vocabulary size show whether learners are adequately equipped with lexical resources for doing various communicative tasks. This way, the words that demand special attention in the L2 classroom can be identified and corrective programs aimed at developing the learners' lexical competence can be devised, all of which should result in a synchronization of the needs of L2 learners and their abilities.

Judging that this issue can be deemed underresearched in the Serbian L1 English L2 learning and teaching context, we decided to explore receptive and productive lexical knowledge of B2-level (CEFR) English learners who have recently completed their final year of secondary education. The current study revealed that Serbian L2 learners' receptive vocabulary is much more developed than their productive vocabulary (approx. 
4,100 word families vs. 2,500 word families). As regards reception, the learners can easily cope with the 3,000 most frequent words of English. But when it comes to production, their competence falls behind as they lack resources even at the 2,000 word frequency level. Accordingly, we surmise that teaching practices to which the learners had been exposed at the primary and secondary level of education did not equally expand their receptive and productive VS. Production-oriented instruction should therefore be introduced in the L2 classroom to boost the learners' productive vocabulary. This could be achieved through intensive reading (i.e. implicitly) or work on projects, presentations, reports, retelling of stories and the like (i.e. explicitly).

We also noticed that the tendency of decreasing word frequency, followed by a decreasing number of correct test items across the test levels, both reception and production-wise, stalls at the level of academic lexis. This implies that the learners are quite familiar with genre-specific lexis characteristic for academic discourse, possibly due to years of exposure to different text styles and types present in B2-level coursebooks (CEFR).

In addition, our findings indicate that receptive vocabulary correlates with productive vocabulary, so the larger a learner's receptive vocabulary size is, the larger his/her productive vocabulary size we can expect. For that reason, we are inclined to believe that the Vocabulary Levels Test (Nation, 1990) can be used in the L2 classroom setting as a useful indication of learners' productive vocabulary size. Moreover, our results demonstrated that the less frequent $L 2$ words were, the wider the gap between lexical reception and production. Whereas this confirms earlier reports (cf. Laufer, 1998; Zhong \& Hirsh, 2009), when we compared the data obtained from two different vocabulary size groups (i.e. the lower and upper proficiency group), we became aware that the gap between receptive and productive vocabulary is narrower for those learners whose competence is more advanced. These observations contradict Laufer's (1998) and call for further inquiry.

\section{References:}

Annen, I. (1933). The Construction, Analysis and Evaluation of a Vocabulary measure (unpublished MA thesis). Eugene: University of Oregon.

Carter, R. (1998). Vocabulary: Applied Linguistic Perspectives. London and New York: Routledge.

Clark, E.V. (1993). The Lexicon in Acquisition. Cambridge: Cambridge University Press.

Cobb, T. (2000). One Size Fits All? Francophone Learners and English Vocabulary tests. Canadian Modern Language Review, Vol. 57, No. 2, 295-324.

Eringa, D. (1974). Enseigner, c'est choisir: vocabulaire-verwerving. Levende Talen, Vol. 36, No. 2, $260-$ 267.

Goulden, R., Nation, P \& Read, J. (1990). How Large Can a Receptive Vocabulary Be? Applied Linguistics, Vol. 11, No. 4, 341-363. 
Lexical knowledge of Serbian L1 English L2 learners: reception vs. production

Laufer, B. \& Nation, P. (1995). Vocabulary Size and Use: Lexical Richness in L2 Written Production. Applied Linguistics, Vol. 16, No. 3, 307-322.

Laufer, B. (1998). The Development of Passive and Active Vocabulary: Same or Different? Applied Linguistics, Vol. 19, No. 2, 255-271.

Laufer, B. \& Nation, P. (1999). A Vocabulary Size Test of Controlled Productive Ability. Language Testing, Vol. 16, No. 1, 33-51.

Marton, W. (1977). Foreign Vocabulary Learning as Problem Number One in Foreign Language Teaching at the Advanced Level. Interlanguage Studies Bulletin, Vol. 2, No. 1, 33-47.

Milton, J. (2009). Measuring Second Language Vocabulary Acquisition. Bristol, Buffalo and Toronto: Multilingual Matters.

Nation, P. (1990). Teaching and Learning Vocabulary. Massachusetts: Newbury House.

Nation, P. (1993). Measuring Readiness for Simplified Material: A Test of the First 1,000 Words of English. In M. L. Tickoo (Ed.), Simplification: Theory and Application (pp. 193-203). Singapore: SAMOE Regional Language Centre.

Nation, I.S.P. (Ed.) (1994). New Ways in Teaching Vocabulary. Alexandria: TESOL.

Nation, I.S.P. (2001). Learning Vocabulary in Another Language. Cambridge: Cambridge University Press.

Nation, P. \& Waring, R. (1997). Vocabulary Size, Text Coverage and Word Lists. In N. Schmitt \& M. McCarthy (Eds.), Vocabulary: Description, Acquisition and Pedagogy (pp. 6-19). Cambridge: Cambridge University Press.

Nation. I.S.P. (2008). Teaching Vocabulary: Strategies and Techniques. Boston: Heinle.

Ozturk, M. (2012). Vocabulary Growth of the Advanced EFL learner. Language Learning Journal. Retrieved November 10, 2014 from the World Wide Web http://www.academia. edu/3206504/Vocabulary_growth_in_intensive_language_study

Olmos, C. (2009). An Assessment of the Vocabulary Knowledge of Students in the Final Year of Secondary Education. Is Their Vocabulary Extensive Enough? International Journal of English Studies, special issue, 73-90.

Read, J. (1988). Measuring the Vocabulary Knowledge of Second Language Learners. RELC Journal, Vol. 19, No. 2, 12-25.

Seashore, R.H. \& Eckerson, L.D. (1940). The Measurement of Individual Differences in General English Vocabularies. Journal of Educational Psychology, Vol. 31, No.1, 14-38.

Schmitt, N. (2000). Vocabulary in Language Teaching. Cambridge: Cambridge University Press.

Schmitt, N., Schmitt, D. \& Clapham, C. (2001). Developing and Exploring the Behaviour of Two New Versions of the Vocabulary Levels Test. Language Testing, Vol.18, No. 1, 55-88.

Schmitt, N. \& McCarthy, M. (Eds.) (1997). Vocabulary: Description, Acquisition and Pedagogy. Cambridge: Cambridge University Press.

Takala, S. (1984). Evaluation of Students'Knowledge of English Vocabulary in the Finnish Comprehensive School. Reports from the Institute for Educational Research 350. Jyväskylä: University of Jyväskylä.

Waring, R. (1997). A Comparison of the Receptive and Productive Vocabulary Sizes of Some L2 Learners. Immaculata Notre Dame Seishin University, No. 1, 53-68. 
Webb, S. (2008). Receptive and Productive Vocabulary Sizes of L2 Learners. Studies in Second Language Acquisition, Vol. 30, No.1, 79-95.

Zhong, H. \& Hirsh, D. (2009). Vocabulary Growth in an English as a Foreign Language Context. University of Sydney papers in TESOL, Vol. 4, No. 1, 85-113.

\section{Подаци о аутору}

Др Јелена Даниловић Јеремић је доцент на Филолошко-уметничком факултету Универзитета у Крагујевцу.

E-mail: jelenadanilce@gmail.com 